\title{
A drowned Mesozoic bird breeding colony from the Late Cretaceous of Transylvania
}

\section{Gareth Dyke, Mátyás Vremir, Gary Kaiser \& Darren Naish}

Naturwissenschaften

The Science of Nature

ISSN 0028-1042

Naturwissenschaften

DOI 10.1007/s00114-012-0917-1

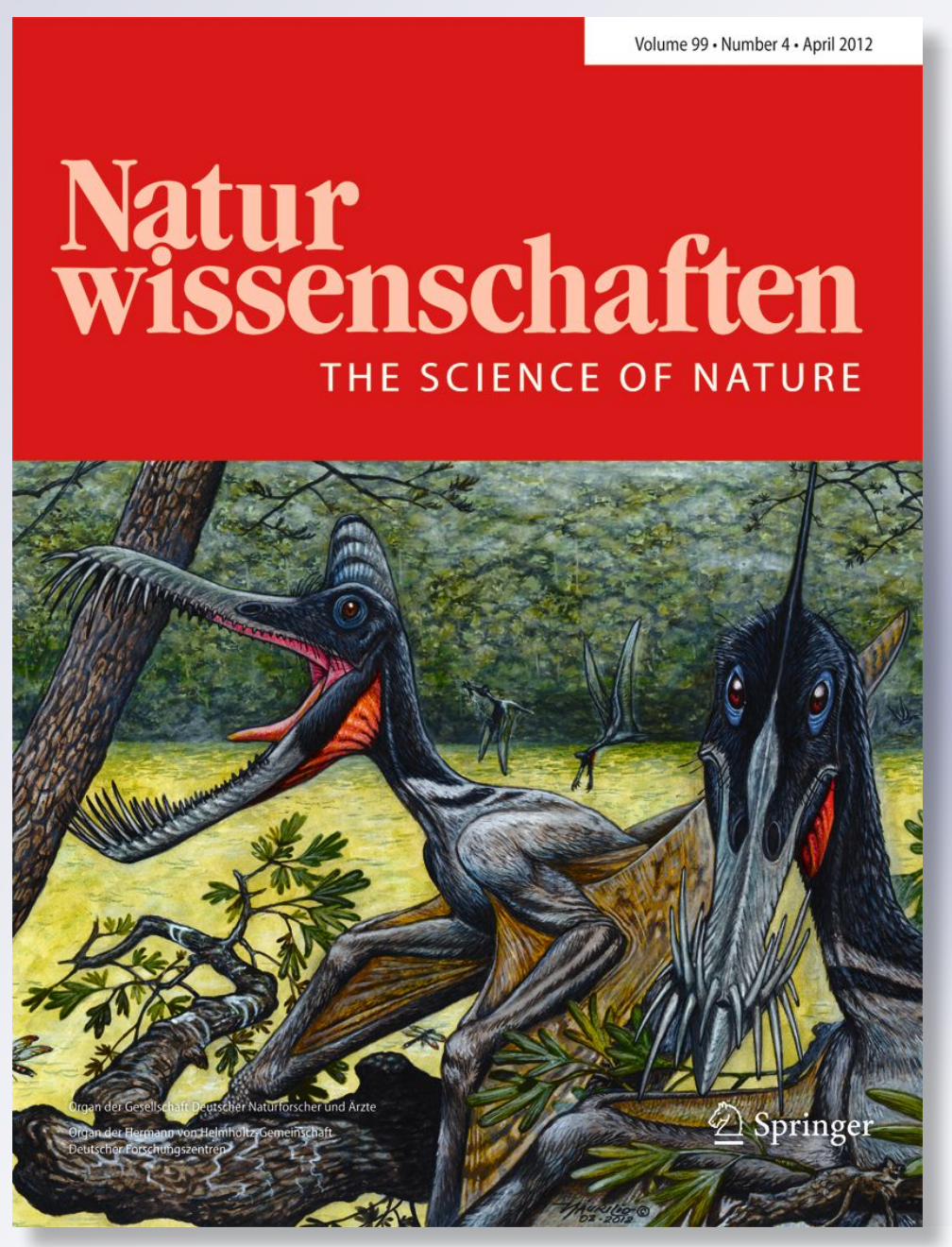

照 Springer 
Your article is protected by copyright and all rights are held exclusively by SpringerVerlag. This e-offprint is for personal use only and shall not be self-archived in electronic repositories. If you wish to self-archive your work, please use the accepted author's version for posting to your own website or your institution's repository. You may further deposit the accepted author's version on a funder's repository at a funder's request, provided it is not made publicly available until 12 months after publication. 


\title{
A drowned Mesozoic bird breeding colony from the Late Cretaceous of Transylvania
}

\author{
Gareth Dyke • Mátyás Vremir • Gary Kaiser • \\ Darren Naish
}

Received: 14 March 2012 / Accepted: 11 April 2012

(C) Springer-Verlag 2012

\begin{abstract}
Despite a rapidly improving fossil record, the reproductive biology of Mesozoic birds remains poorly known: only a handful of undisputed, isolated Cretaceous eggs (some containing embryonic remains) are known. We report here the first fossil evidence for a breeding colony of Mesozoic birds, preserved at the Late Cretaceous (Maastrichtian) Oarda de Jos (Od) site in the Sebeș area of Transylvania, Romania. A lens of calcareous mudstone with minimum dimensions of $80 \mathrm{~cm}$ length, $50 \mathrm{~cm}$ width and $20 \mathrm{~cm}$ depth contains thousands of tightly packed, morphologically homogenous eggshell fragments, seven near-complete eggs and neonatal and adult avialan skeletal elements. Eggshell forms $70-80 \%$ of the matrix, and other fossils are entirely absent. The bones exhibit clear characters of the Cretaceous avialan clade Enantiornithes, and the eggshell morphology is also consistent with this identification. Both taphonomy and lithology show that the
\end{abstract}

Communicated by: Robert Reisz

G. Dyke $(\bowtie) \cdot$ D. Naish

Ocean and Earth Science, National Oceanography Centre,

Southampton, University of Southampton,

Southampton SO14 3ZH, UK

e-mail: gareth.dyke@soton.ac.uk

D. Naish

e-mail: eotyrannus@gmail.com

M. Vremir

Department of Natural Sciences,

Transylvanian Museum Society (EME),

2-4 Napoca Street,

Cluj-Napoca 400009, Romania

e-mail: vremirmatyi@yahoo.co.uk

\section{G. Kaiser}

Royal British Columbia Museum,

Victoria, BC, Canada

e-mail: gansus@shaw.ca components of this lens were deposited in a single flood event, and we conclude that it represents the drowned remains of a larger enantiornithine breeding colony, swamped by rising water, washed a short distance and deposited in a shallow, low-energy pond. The same fate often befalls modern bird colonies. Such a large concentration of breeding birds suggests aquatic feeding in this species, augments our understanding of enantiornithine biology and shows that colonial nesting was not unique to crown birds.

Keywords Avialae $\cdot$ Enantiornithes $\cdot$ Eggs $\cdot$ Oology Nesting behaviour $\cdot$ Hatching

\section{Introduction}

Despite a dramatic improvement in the number of fossil birds known from the Mesozoic over the last decade, our understanding of egg morphology and nesting behaviour in Mesozoic birds remains sparse. Just a handful of Mesozoic taxa are known from embryonic remains (Elzanowski 1981; Schweitzer et al. 2002), and even less are associated with egg shell and/or complete eggs (Grellet-Tinner and Norell 2002; Mikhailov 1996; Schweitzer et al. 2002; Zhou and Zhang 2004). Of particular note, a single unhatched enantiornithine egg, containing the remains of a clearly precocial embryo (with well-developed primary feather tracts), has been described from the Early Cretaceous of China (Zhou and Zhang 2004). Nothing is known about the breeding behaviours of Mesozoic birds; In this paper, we present a remarkable eggshell, egg and bone accumulation from the Late Cretaceous of Transylvania, Romania (Vremir 2010) (Fig. 1), that provides the first direct evidence for colonial breeding in Cretaceous birds. This fossil accumulationtermed here the Od accumulation (Oarda de Jos) - is a lens 

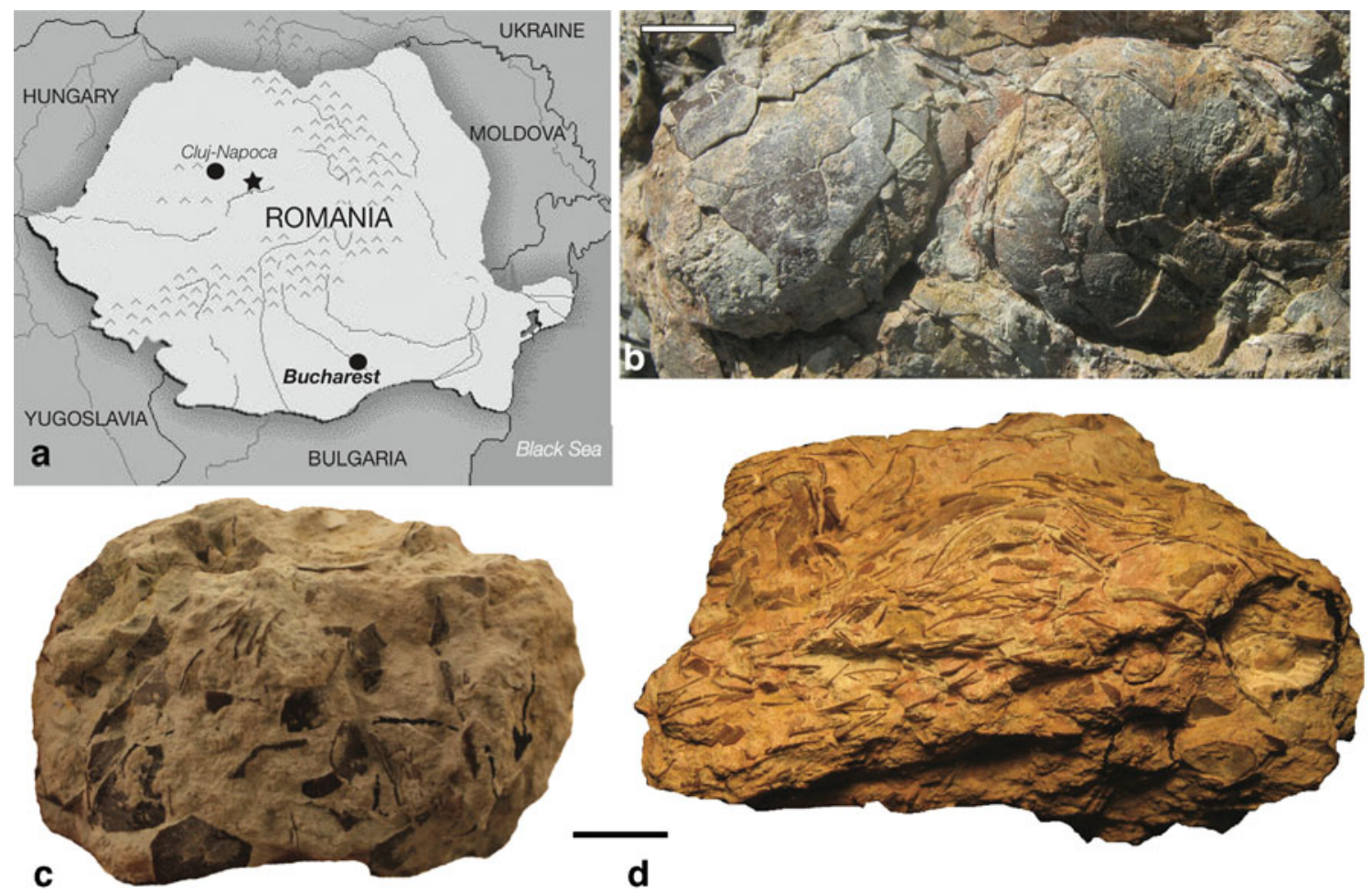

Fig. 1 The Od accumulation (Late Cretaceous: Sebeș, Romania): a map showing the location of the Od site (star), b two of the seven partial enantiornithine eggs from the upper layer, $\mathbf{c}$ matrix supported mudstone

in the upper layers of the lens, $\mathbf{d}$ shell-supported material from lower portions of the lens. Scale bars are $1 \mathrm{~cm}$

of calcareous mudstone composed of thousands of morphologically homogenous eggshell fragments associated with a number of near-complete eggs $(n=7)$, complete and identifiable bird bones $(n=12)$ and numerous indeterminate bone fragments $(n=\sim 50$; the entire lens was collected in pieces and is now housed in the Transylvanian Museum Society museum, Cluj-Napoca, Romania as EME V.314) (Fig. 1b-d). The accumulation was collected from the basal fluvio-paludal part of the Od outcrop in the Maastrichtian Sebeş Formation, which outcrops about $100 \mathrm{~km}$ from the city of Cluj-Napoca in western Romania (Vremir 2010; Fig. 1a).

In parts of the Od calcareous lens, $70-80 \%$ of the rock is formed by eggshell fragments (Fig. 1d). The remainder is a calcareous matrix representing a floodplain limestone facies (Codrea and Dica 2005; Codrea et al. 2010; Csiki et al. 2010; Therrien et al. 2002; Vremir 2010). As we discuss, the bones, eggshell fragments and near-complete eggs all appear to belong to the same avialan taxon (a member of the Cretaceous clade Enantiornithes).

\section{Geology and taphonomy}

Continental outcrops of the Maastrichtian Sebes Formation occur in the southwestern part of the Transylvanian sedimentary basin (including the well-known "Râpa Roșie" or Red Cliffs)

(Vremir 2010). The most productive vertebrate localities are distributed along the southwestern part of the Transylvanian Basin in the vicinity of the town of Sebeș (Codrea and Dica 2005; Codrea et al. 2010; Csiki et al. 2010; Vremir 2010; Fig. 1a). The calcareous lens described here comes from the middle section of the Sebeș Formation, characterised by laterally extensive sandy channel fills of a meandering fluvial system, silty crevasse splays, locally developed ponded calcareous mudstones with thin coal layers and extensive brownish-red fine overbank deposits (Vremir 2010; Fig. 2).

Few associated skeletal remains have been collected from the Sebeş Formation. Ornithopod hind limb elements, a partial lizard skeleton, a partially articulated medium-sized azhdarchid pterosaur and the dromaeosaurid Balaur bondoc (Csiki et al. 2010; Vremir 2010) all come from the reddish overbank sediments (Fig. 2).

The Od accumulation itself comprises a distinct calcareous lens, collected almost in entirety from above the reddish overbank mudstone mentioned above. Palaeocurrent data associated with the accumulation show a northeast flow direction (i.e. almost perpendicular to the outcrop face; Fig. 2a) and bone, egg and eggshell preservation in the accumulation is consistent with a very short transport distance from a river bank or sandbar into a small, shallow pond trapped by rising water: All bones are unabraded, and seven almost complete eggs are preserved. A seasonal, tropical monsoonal climate 
Fig. 2 a The Oarda de Jos vertebrate locality (Od.A1 and A2), Maastrichtian, Sebeș Formation (after Vremir 2010, modified) $\mathbf{b}$ the Od site in the Sebeș river
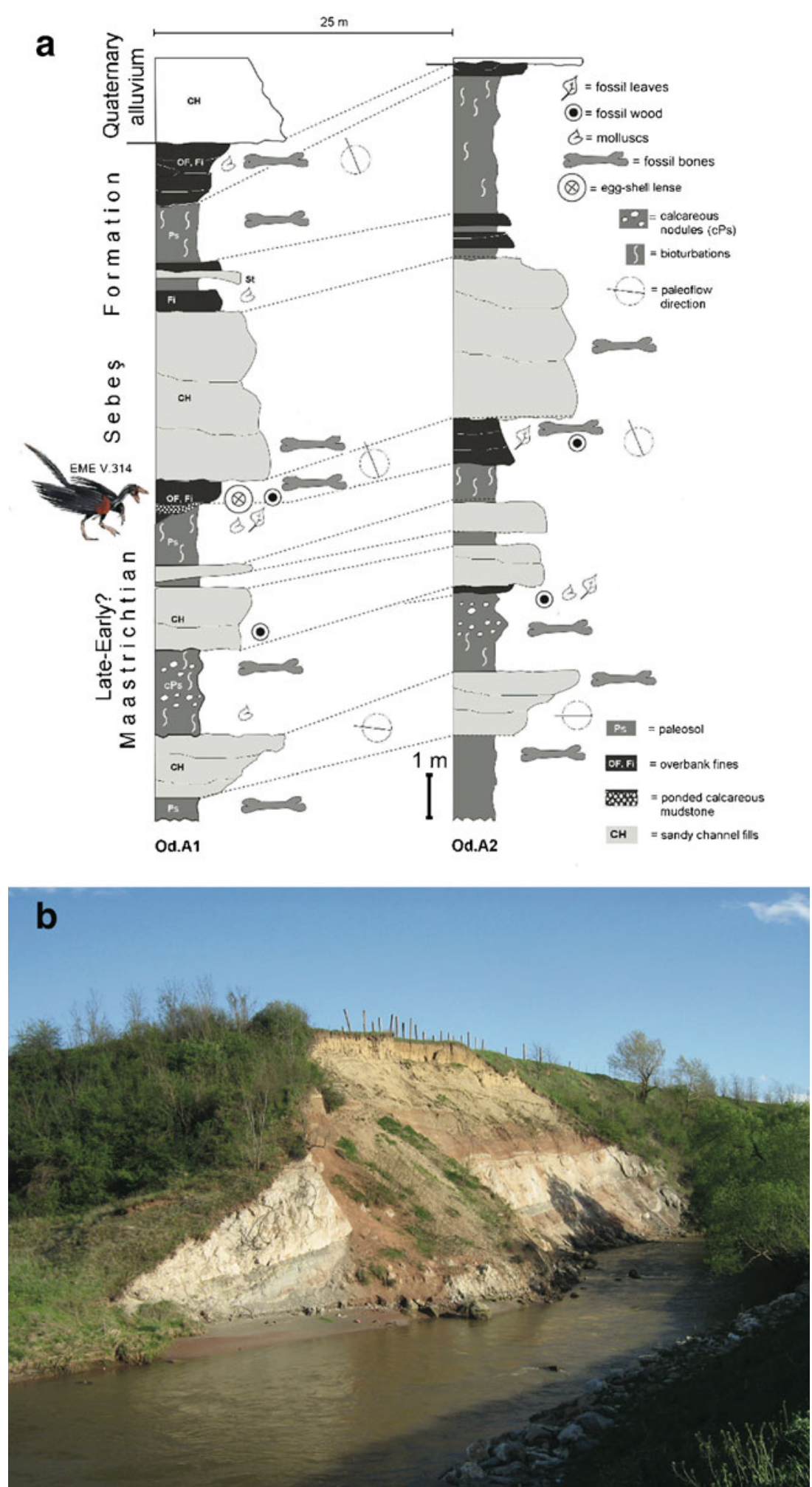

with long dry periods followed by short, wet bursts has been inferred for the Maastrichtian in this region (Therrien et al. 2002; Therrien 2005; Vremir 2010). Periodic floods, sometimes extreme, have also been demonstrated based on sedimentological evidence (Therrien et al. 2002).
Much smaller but similar avialan eggshell-supported limestone accumulations have been described from the contemporaneous Hațeg Basin of Transylvania (Van Itterbeeck et al. 2004) and from the Paleocene of the Clarks Fork Basin, Wyoming (Bowen and Bloch 2002). The sedimentology and 
interpretation of these limestones are very similar (Therrien et al. 2002; Therrien 2005), the differences being the smaller size of the Wyoming specimens and structure of the fossil assemblage from Sebeș: as far as can be determined, the Od accumulation is monospecific.

\section{Description}

Cursory examination of the Od accumulation reveals it to be a consolidated mass of literally thousands of brown-grey eggshell fragments, tightly packed together but separated by sediment (Figs. 1c, d, 3). The quantity of eggshell fragments in the Od accumulation is astonishing and beyond normal palaeontological experience, with $70-80 \%$ of the lens' volume formed by eggshell throughout the ca. $80 \times 50 \times 20$ $\mathrm{cm}$ dimensions of the accumulation: 153 shell fragments are present in one $26-\mathrm{cm}^{2}$ section from near the base of the lens (mean exposed shell fragment length, $36 \mathrm{~mm} \pm 0.126 \mathrm{SD}$ ). One of the almost complete sub-rounded eggs is $4.0 \times 2.5 \mathrm{~cm}$ in dimensions and would have had a volume of around $11 \mathrm{~cm}^{3}$ (using equations in Hoyt 1979). Using these calculations as a basis, eggs occur at high density in the sample, ca. 46 whole eggs per $100 \mathrm{~cm}^{3}$.

The inner surfaces of eggshell fragments are dull and etched in places (Fig. 4e), suggesting that calcium mobilisation was advanced and that the eggs had either hatched or were destroyed late in the second half of incubation (Simkiss 2004; Board and Sparks 2004). This is corroborated by the presence of broken, jumbled juvenile bone fragments within the accumulation. Scanning electron microscopy (SEM) of the Od eggshell fragments shows that they comprise compact shell units with calcite crystals

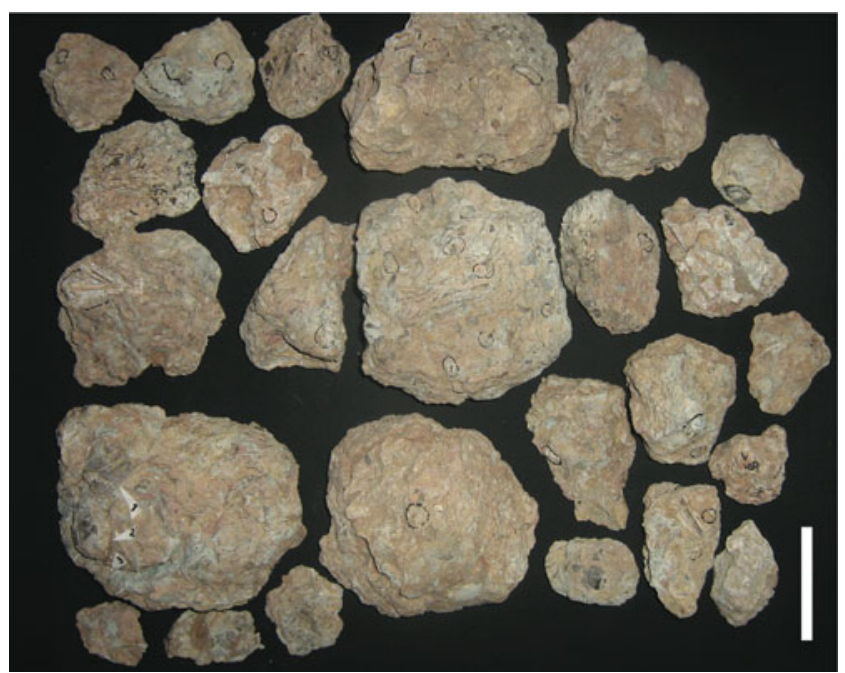

Fig. 3 The entire Oarda de Jos calcareous lens as collected and prior to preparation of individual pieces. Scale bar is $5 \mathrm{~cm}$ forming two large, distinct layers that are similar in thickness (Fig. 4a), a morphology consistent with previous descriptions of ornithothoracine bird eggs (see, for e.g. Grellet-Tinner et al. 2006). Further descriptions and microcharacterisation of eggs and shells will be presented in later work.

Some of the adult bones (humerus, scapula and coracoid; Fig. 4f, g) preserve characters hypothesised in phylogenetic studies to be enantiornithine synapomorphies (i.e. dorsal margin of the humeral head concave centrally, rising ventrally and dorsally; costal surface of scapula blade with prominent, longitudinal furrow; pit between acromion and humeral articular facet on proximal end of scapula absent; coracoid with laterally compressed dorsal end and almost aligned acrocoracoid process, humeral articular surface and scapular facet) (Chiappe and Witmer 2002; O'Connor et al. 2009, 2011). The surfaces of the Od eggshells also lack marked ornamentation (Fig. 4e), a character hypothesised by some authors as a synapomorphy of Avialae with respect to other theropods (Grellet-Tinner et al. 2006; O'Connor et al. 2011); furthermore, the presence of two subequal prismatic eggshell layers (rather than three) in section (Fig. 4a) implies (based on some analyses) that these shells can be excluded from the avialan clade Ornithuromorpha (sensu Grellet-Tinner et al. 2006), consistent with our osteological enantiornithine determination (Chiappe and Witmer 2002; O'Connor et al. 2009, 2011). Note that although the phylogenetic distribution of these features is debated and may be more widespread among theropods (Zelenitsky and Therrien 2008; Jackson et al. 2010), the eggshell characters we list are consistent with our osteological identification of the Od birds.

Indeed, the Od accumulation bones correspond in morphology and dimensions with those of Enantiornis from Argentina (Walker 1981; Chiappe 1993; Walker and Dyke 2010), strongly suggesting that they come from the same, or a similar, taxon. The proximal section of a humerus (Fig. 4f) has a saddle-shaped head that is convex and separated from the bicipital crest by a deep, wide ligamental groove. The bicipital crest is robust, rounded, anteriorly projecting and bears a distinct but narrow pneumatic fossa (as in Enantiornis) (Walker and Dyke 2010); the deltopectoral crest is prominent and flat. Incipient pneumatisation of this region via a small pneumatic fossa is shared with similarly sized Argentine enantiornithines, particularly Enantiornis (Walker 1981; Walker and Dyke 2010). An adult scapula from the Od assemblage is robust, straight and with a welldeveloped, straight acromion, a medial longitudinal groove (Fig. 4g) and a depression anterior to the coracoid articulation. The dorsal end of a large coracoid from the assemblage bears a fenestra in its medial wall. All of these features are also present in Enantiornis (Walker 1981; Chiappe 1993; Walker and Dyke 2010). The anterior portion of a sternum, 
with non-overlapping coracoidal sulci and no spina, also fits the size range of this taxon (Fig. 4h).

In a further effort to determine the affinities of the adult bones within the assemblage, we compared them with elements described for other Late Cretaceous enantiornithines from Eastern and Central Europe. Ösi (2008) reported an enantiornithine femur and tarsometatarsus from the Santonian Csehbánya Formation of Iharkút, Hungary, as well as a number of limb elements identified as those of indeterminate avialans. Dyke and Ösi (2010) described additional Iharkút enantiornithine specimens and named the Iharkút tarsometatarsus as the new avisaurid Bauxitornis mindszentyae. Ösi and Buffetaut (2008) described two enantiornithine femora from Iharkút and suggested that they might be referable to Bauxitornis. Unfortunately, none of these elements overlap with those present in the Od accumulation. Wang et al. (2011) described two enantiornithine humeri from the Hateg Basin that differ in the shapes of their proximal ends from the element present in the Od assemblage: the caput humeri of the Od enantiornithine and Enantiornis is smoothly rounded, whereas in the specimens described by Wang et al. (2011) the head is raised proximally and is more angular. This may very well be a size-related difference, but more fossils will be required to test this supposition.

The Od accumulation also includes numerous smaller, broken bones. These elements are mostly indeterminate, slender, thin-walled and hollow, but a quadrate, pedal phalanges, cervical and dorsal vertebrae, proximal end of a tibiotarsus and scapula (Fig. 4c-e, g-j) are also present. Identifiable elements evidently belong to avialan theropods, and we suggest that, because of their incomplete development and size, they all belong to neonate birds. Of these smaller elements, the scapula is robust and has a welldeveloped, squared-off acromion, consistent with an enantiornithine identification (Chiappe and Witmer 2002; O'Connor et al. 2009, 2011) (Fig. 4j).

\section{Discussion}

Our interpretation is that the Od accumulation represents a breeding colony of Late Cretaceous (Maastrichtian) enantiornithines. As such, it significantly augments our understanding of enantiornithine biology. Firstly, the obvious proximity of the drowned colony to a water course might suggest aquatic feeding habits for this species only because there is a consistent link between aquatic foraging and the habit of nesting on sandbars and riverbanks in extant birds. While some enantiornithines were denizens of inland, terrestrial environments, stomach contents (Sanz et al. 1996) and morphological adaptations suggest that at least some members of the group were aquatic foragers (Sanz and Buscalioni 1992). We conclude that the proximity of the Od nesting colony to water provides additional evidence for this view of aquatic enantiornithines. Nesting in close proximity to water brings the danger of flooding (Kharatinov and Siegel-Causey 1988); this is a major cause of nest mortality in extant waterfowl (Whitehead and Tschimer 1990; Flint and Grand 1996), terns (Sidle et al. 1992; Ludwig et al. 1993), plovers (Espie et al. 1998), flamingos (Brown 1957) and other birds, and can cause destruction of an entire
Fig. 4 Eggshell, some adult and neonate avialan bones from the Od accumulation: a SEM image of sample eggshell section with two main structural layers indicated with arrows. Scale bar is $100 \mu \mathrm{m}$. Neonate avialan cervical vertebra (b), pedal phalanx (c) and dorsal vertebra (d) (scale bar in (b) and (c) is $2 \mathrm{~mm}$, in (d), $1 \mathrm{~mm}$ ). e Eggshell shown from the inside (in) and outside (o), alongside neonate avialan quadrate (arrow). Adult enantiornithine humerus (f), scapula (g) and sternum (h) (scale bars are $1 \mathrm{~cm}$ ). Neonate avialan proximal tibiotarsus (i) and scapula (j) (scale bars are $2 \mathrm{~mm}$ )

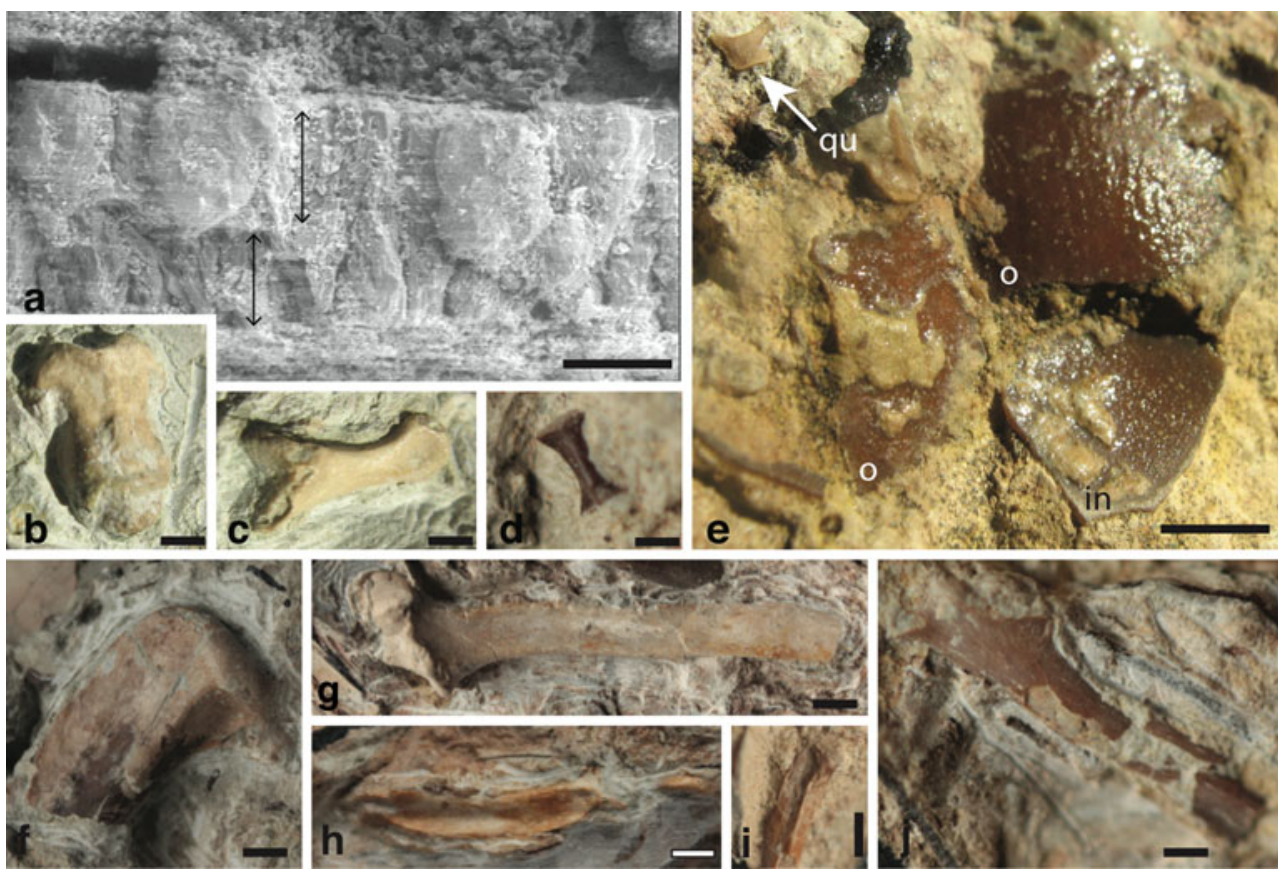


colony (Brown 1957; Peresbarbosa and Mellink 2001; Poiani 2006), on occasion repeatedly during the same breeding season (Peresbarbosa and Mellink 2001). Birds continue to select these sites in future nesting seasons, partly because floods remove vegetation and increase the amount of barren ground suitable for near-water nesting (Sidle et al. 1992).

The near-complete eggs in the accumulation are bluntly pointed and slightly asymmetric in profile (Fig. 1b), similar in shape to eggs produced by modern ground-nesting birds with precocial or semi-precocial young (Mao et al. 2007). Their slightly pointed shape would have affected the pattern of heat loss (Smart 2004; Mao et al. 2007) but more likely would have both facilitated gas exchange by creating space for a large air cell (Grellet-Tinner et al. 2006; Mao et al. 2007), and allowed the eggs, just like all other bird eggs, to lie naturally on one side, with the pore-rich, blunt end elevated (Board and Sparks 2004; Mao et al. 2007; Fig. 1b). The more complete Od eggs are at least $50 \%$ larger than the handful of other Mesozoic ornithothoracine eggs associated with embryonic bones (Elzanowski 1981; Mikhailov 1996; Grellet-Tinner and Norell 2002; Schweitzer et al. 2002; Zhou and Zhang 2004; GrelletTinner et al. 2006). These observations, their broken polar regions (Fig. 1b), and the absence of any remaining bone fragments within the two near-complete eggs (Paul Tafforeau, European Synchrotron Radiation Facility, personal communication 2011), are consistent with the interpretation that they are hatched and that (like other reported Cretaceous bird eggs) they belonged to ground-nesting birds (Schweitzer et al. 2002; Mikhailov 1996; Grellet-Tinner et al. 2006): the polar region adjacent to the air cell is often
Fig. 5 Additional adult and neonate enantiornithine bones from the Od accumulation: a complete ulna (total preserved length, $75 \mathrm{~mm}$ ), b complete tibiotarsus (total preserved length, $75 \mathrm{~mm}$ ), c proximal humerus (total preserved length, $11 \mathrm{~mm}$ )
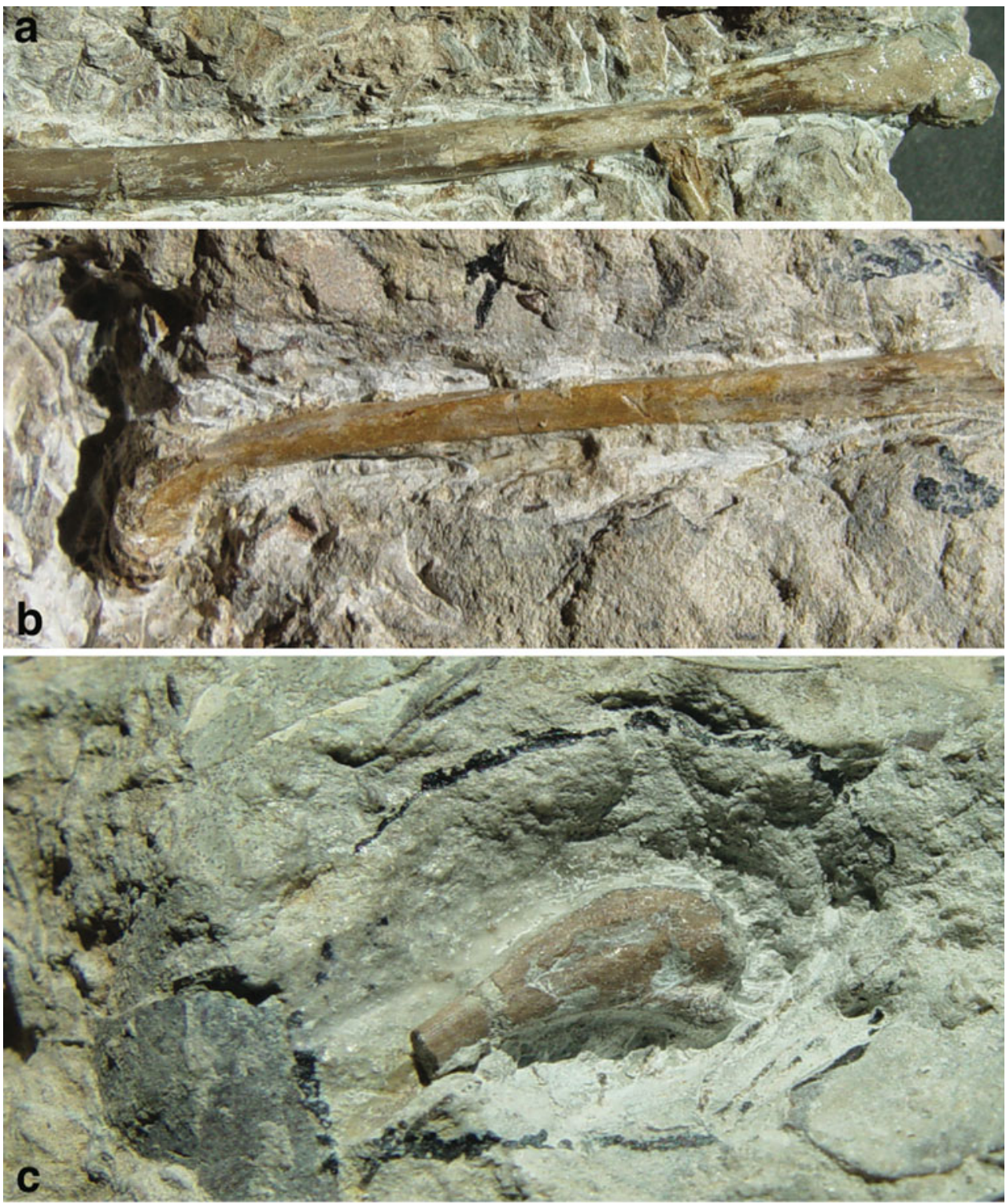
destroyed after hatching in gull colonies (Hayward et al. 2000), as is the case here (Fig. 1b).

The abundance of eggshell, eggs and juvenile bones (and their uniformity of preservation, implying a similar taphonomic history) that make up the assemblage suggests synchronous breeding and colonial nesting (Figs. 4 and 5). This is unsurprising: Synchronous breeding in large colonies is a widespread and successful strategy in modern birds, with the largest examples most often located at secure sites like offshore islands or sandbars surrounded by flowing water. However, large colonies present birds with the problem of feeding both themselves and large numbers of young over extended periods of time. Living birds solve this problem with strong flight and the ability to disperse across large areas in search of food. Strong flight has been suggested for some larger enantiornithines, like Enantiornis (cf. the Od bones) and Martinavis, known from fossil specimens widely separated geographically (Walker et al. 2007). The presence of possibly synchronous, colonial breeding in turn implies that the Od enantiornithines were taking advantage of seasonally abundant but localised food resources. The adult birds may have nested as early as possible, balancing the risk of flooding against the advantages of early access to this constrained resource: the colonial nesting Red-billed quelea Quelea quelea, for example, breeds in the second half of the rainy season when insects are most abundant (Mundy and Herremans 1997). It is unknown whether the associated adults were involved in the care of eggs, nests or juveniles, but their presence at least implies some parental care in this bird: an unhatched egg from China indicates that the young of some enantiornithines were precocial (Zhou and Zhang 2004). The Od accumulation is clear evidence that waterside colonial nesting was present in Cretaceous birds, but also that this habit was far from unique to crown birds (Neornithes).

Acknowledgments We thank E. Buffetaut, A. Clark, Z. Csiki, A. Dulai, J. Dyke, G. Grellet-Tinner, E. Hankó, R. Hebda, R. Horn, F. Jackson, E. Kurochkin, A. Ösi, J. O'Connor, P.M. Sander, P. Tafforeau, D. Varricchio, X. Wang, two anonymous reviewers, R. Reisz and S. Thatje for their help with this project and for detailed comments on the manuscript.

\section{References}

Board RG, Sparks NHC (2004) Shell structure and formation in avian eggs. In: Deeming DC, Ferguson MWJ (eds) Egg incubation: its effect on embryonic development in birds and reptiles. Cambridge University Press, Cambridge, pp 71-86

Bowen GJ, Bloch JI (2002) Petrography and geochemistry of floodplain limestones from the Clarks Fork Basin, Wyoming, U.S.A.: carbonate deposition and fossil accumulation on a PaleoceneEocene floodplain. J Sed Res 72:46-58

Brown HD (1957) The breeding of the lesser flamingo in the Mweru Wantipa, northern Rhodesia. Ibis 99:688-692
Chiappe LM (1993) Enantiornithine (Aves) tarsometatarsi from the Cretaceous Lecho Formation of northwestern Argentina. Am Mus Novit 3083:1-27

Chiappe LM, Witmer LM (2002) Mesozoic birds: above the heads of dinosaurs. University of California Press, Berkeley

Codrea V, Dica P (2005) Upper Cretaceous-Lowermost Miocene lithostratigraphic units in Alba Iulia-Sebeș-Vintu de Jos area (SW Transylvanian Basin). Studia Universitatis Babes-Bolyai, Geologia 50:19-26

Codrea V, Vremir M, Jipa C, Godefroit P, Csiki Z, Smith T, Fărcaș C (2010) More than just Nopcsa's Transylvanian dinosaurs: a look outside the Hațeg Basin. Palaeogeogr Palaeoclimatol Palaeoecol 293:391-405

Csiki Z, Vermir M, Brusatte SL, Norell MA (2010) An aberrant islanddwelling theropod dinosaur from the Late Cretaceous of Romania. Proc Nat Acad Sci 107:15357-15361

Dyke GJ, Ösi A (2010) A review of Late Cretaceous fossil birds from Hungary. Geol J 45:434-444

Elzanowski A (1981) Embryonic skeletons from the Late Cretaceous of Mongolia. Pal Pol 42:147-179

Espie RHM, James PC, Brigham RM (1998) The effects of flooding on piping plover Charadrius melodus reproductive success at Lake Diefenbaker, Saskatchewan, Canada. Biol Conserv 86:215-222

Flint PL, Grand JB (1996) Nesting success of Northern pintails on the coastal Yukon-Kuskokwim Delta, Alaska. Condor 98:54-60

Grellet-Tinner G, Norell MA (2002) An avian egg from the Campanian of Bayn Dzak, Mongolia. J Vert Paleontol 22:719-721

Grellet-Tinner G, Chiappe LM, Norell MA, Bottjer D (2006) Dinosaur eggs and nesting behaviours: a paleobiological study. Palaeogeog Palaeoclimatol Palaeoecol 232:294-321

Hayward JL, Zelenitsky DK, Smith DL, Zaft DM, Clayburn JK (2000) Eggshell taphonomy at modern gull colonies and a dinosaur clutch site. Palaios 15:343-355

Hoyt DF (1979) Practical methods of estimating volume and fresh weight of bird eggs. Auk 96:73-77

Jackson FD, Horner JR, Varricchio DV (2010) A study of a Troodon egg containing embryonic remains using epifluorescence microscopy and other techniques. Cret Res 31:255-262

Kharatinov SP, Siegel-Causey D (1988) Colony formation in birds. In: Johnston RF (ed) Current ornithology, vol. 5. Plenum, New York, pp 223-272

Ludwig JP, Auman HJ, Kurita H, Ludwig ME, Campbell LM, Giesy JP, Tillitt DE, Jones P, Yamashita N, Tanabe S, Tatsukawa R (1993) Caspian tern reproduction in the Saginaw Bay ecosystem following a 100-year flood event. J Great Lake Res 19:96-108

Mao KM, Murakami A, Iwasawa A, Yoshizaki N (2007) The asymmetry of avian egg-shape: an adaptation for reproduction on dry land. J Anat 210:741-748

Mikhailov KE (1996) Bird eggs in the Upper Cretaceous of Mongolia. Pal J 30:114-116

Mundy PJ, Herremans M (1997) Redbilled Quelea Quelea quelea. In: Harrison J, Allan D, Underhill L, Herremans M, Parker V, Brown CJ (eds) The atlas of Southern African birds. Avian Demography Unit, Cape Town, pp 573-575

O'Connor JK, Wang X-R, Chiappe LM, Gao C-H, Meng Q-J, Cheng X-D, Liu J-Y (2009) Phylogenetic support for a specialized clade of Cretaceous enantiornithine birds with information from a new species. J Vert Paleontol 29:188-204

O'Connor JK, Chiappe LM, Bell A (2011) Pre-modern birds: avian divergences in the Mesozoic. In: Dyke GJ, Kaiser G (eds) Living dinosaurs: the evolutionary history of modern birds. Wiley Blackwell, London, pp 39-114

Ősi A (2008) Enantiornithine bird remains from the Late Cretaceous of Hungary. Oryctos 7:55-60

Ösi A, Buffetaut E (2008) Additional non-avian theropod and bird remains from the early Late Cretaceous (Santonian) of Hungary 
and a review of the European abelisauroid record. Annales de Paléontologie 97:35-49

Peresbarbosa E, Mellink E (2001) Nesting waterbirds of Isla Montague, northern Gulf of California, México: loss of eggs due to predation and flooding, 1993-1994. Waterbirds 24:265-271

Poiani A (2006) Effects of floods on distribution and reproduction of aquatic birds. Adv Ecol Res 39:63-83

Sanz JL, Buscalioni AD (1992) A new bird from the Early Cretaceous of Las Hoyas, Spain, and the early radiation of birds. Palaeontol $35: 829-845$

Sanz JL, Chiappe LM, Pérez-Moreno B, Buscalioni AD, Moratalla JJ, Ortega F, Poyata-Ariza FJ (1996) An Early Cretaceous bird from Spain and its implications for the evolution of avian flight. Nature 382:442-445

Schweitzer MH, Jackson FD, Chiappe LM, Schmitt JG, Calvo JO, Rubilar DE (2002) Late Cretaceous avian eggs with embryos from Argentina. J Vert Paleontol 22:191-195

Sidle JG, Carlson DE, Kirsch EM, Dinan JJ (1992) Flooding: mortality and habitat renewal for Least terns and Piping plovers. Colonial Waterbirds 15:132-136

Simkiss K (2004) Fluxes during embryogenesis. In: Deeming DC, Ferguson MWJ (eds) Egg incubation: its effect on embryonic development in birds and reptiles. Cambridge University Press, Cambridge, pp 47-52

Smart IHM (2004) Egg shape in birds. In: Deeming DC, Ferguson MWJ (eds) Egg incubation: its effect on embryonic development in birds and reptiles. Cambridge University Press, Cambridge, pp 101-116

Therrien F (2005) Palaeoenvironments of the latest Cretaceous (Maastrichtian) dinosaurs of Romania: insights from fluvial deposits and paleosols of the Transylvanian and Hațeg basins. Palaeogeog Palaeoclimatol Palaeoecol 218:15-56
Therrien F, Jianu C-M, Bogdan S, Weishampel DB, King JW (2002) Palaeoeonvironmental reconstructions of latest Cretaceous dinosaur-bearing formations of Romania: preliminary results. Sargetia 11:33-59

Van Itterbeeck J, Sasaran E, Codrea V, Sasaran L, Bultynk P (2004) Sedimentology of the Upper Cretaceous mammal- and dinosaurbearing sites along the Raul Mare and Barbat rivers, Hatseg Basin, Romania. Cret Res 25:517-530

Vremir M (2010) New faunal elements from the Late Cretaceous (Maastrichtian) continental deposits of Sebeș area (Transylvania). Acta Musei Sabesiensis 2:635-684

Walker CA (1981) New subclass of birds from the Cretaceous of South America. Nature 292:51-53

Walker CA, Dyke GJ (2010) Euenantiornithine birds from the Late Cretaceous of El Brete (Argentina). Ir J Earth Sci 27:15-62

Walker CA, Buffetaut E, Dyke GJ (2007) Large euenantiornithine birds from the Cretaceous of southern France, North America and Argentina. Geol Mag 144:977-986

Wang X, Dyke GJ, Codrea V, Godefroit P, Smith T (2011) A euenantiornithine bird from the Late Cretaceous Hateg Basin of Romania. Acta Pal Pol 56:853-857

Whitehead PJ, Tschimer K (1990) Magpie goose, Anseranas semipalmata, nesting on the Mary River floodplain, Northern Territory, Australia - extent and frequency of flooding losses. Australian Wildl Res 17:147-157

Zelenitsky DK, Therrien F (2008) Phylogenetic analysis of reproductive traits of maniraptoran theropods and its implications for parataxonomy. Palaeontol 51:807-816

Zhou Z, Zhang F (2004) A precocial avian embryo from the Lower Cretaceous of China. Science 306:653 